\title{
DILTIAZEM PREVENTS MONOSODIUM GLUTAMATE TOXICITY IN THE RAT TESTES
}

\author{
Vladmila Bojanić ${ }^{1}$, Stevo Najman ${ }^{2}$, Aleksandra Veličkov ${ }^{3}$, Novica Bojanić4, Jelena Milenković1
}

\begin{abstract}
Increased exposure to food additives may exhibit harmful effect on the male reproductive system. Neonatal application of high doses of popular taste enhancer monosodium glutamate (MSG) to different kinds of animals cause lesions of the hypothalamic nuclei and the retina. Later in adulthood, animals exhibit a series of neuroendocrine disorders (stunted growth, obesity and decreased fertility).

The mechanism of MSG action is not completely explained yet. We hypothesized that high concentration of MSG could alter permeability of neural membrane for calcium. The objective of our study was to find out whether the pretreatment with diltiazem, a calcium channel blocker, could prevent harmful effect of MSG in the rat testes. Male rat pups were treated with: $0.9 \%$ sodium chloride (C group), $4 \mathrm{mg} / \mathrm{g}$ BW of MSG (M group), $5 \mathrm{mg} / \mathrm{g}$ BW of diltiazem (D group) and diltiazem $5 \mathrm{mg} / \mathrm{g}$ BW with MSG (DM group) on $2^{\text {nd }}, 4^{\text {th }}, 6^{\text {th }}, 8^{\text {th }}, 10^{\text {th }}$ postnatal day. Animals were sacrificed at the age of six months. MSG treatment resulted in: stunted growth (decreased naso-anal length and tail length; $p<0.05$ ), decreased relative testis weight $(p<0.05)$, and increased adipose tissue mass (Lee index; $p<0.05$ ), testicular atrophy and decreased histomorphometric parameters (tubular area, tubular perimeter, Feret diameter, tubular diameter, epithelial height; $p<0.001$ ). The rats of $C, D$ and DM groups had normal testicular histology and morphometric parameters. Pretreatment with diltiazem has prevented the development of morphological disorders of testes. Our results suggest that calcium overloading may play an important role among mechanisms of MSG testicular toxicity.
\end{abstract}

Acta Medica Medianae 2020;59(3):20-26. toxicity

Key words: monosodium glutamate, diltiazem, morphometric parameters, testes,

${ }^{1}$ University of Niš, Faculty of Medicine, Department of Pathophysiology, Niš, Serbia

${ }^{2}$ University of Niš, Faculty of Medicine, Department of Biology and human genetics, Niš, Serbia

${ }^{3}$ University of Niš, Faculty of Medicine, Department of Histology and embryology, Nišs, Serbia

${ }^{4}$ University of Niš, Faculty of Medicine, Research center for biomedicine, Niš, Serbia

Contact: Vladmila Bojanić

11/37 Pariske komune St., 18000 Niš, Serbia

E-mail: vladmilab@gmail.com most often attributed to: infections, the negative influence of alcohol, cigarette smoking habit, drug addiction, exposition to heat, excessive exercising, overweight or underweight, exposition to toxic products (lead, cadmium, etc.) and iatrogenic factors (7-10).

A certain risk is hidden in increased use of food additives like monosodium glutamate (MSG). This popular taste enhancer is widely used in commercial and domestic food preparation. MSG is the salt of nonessential glutamic acid. It has a property to enhance the perception that flavors are well blended and full-bodied and disguise unwelcome tastes. This additive is present in almost all food products: dehydrated soups or sauces, canned and frozen foods and meals, fresh sausages, marinated meats, and stuffed or seasoned chicken, bottled soy or oriental sauces, manufactured meats, some hams, flavored tuna, vegetarian burgers and sausages, flavored chips and snacks (11-14).

Numerous studies have shown that application of high doses of MSG (1-4 mg/g BW) especially during the neonatal period may cause lesions of the preoptic nuclei, arcuate nuclei, the circumventricular organs and the retina in different kinds of animals (mice, rats, rabbits, hamsters, dogs, and monkeys) 
(13, 15-26). During later life MSG treated animals exhibit a series of neuroendocrine disorders: stunted growth, obesity and decreased fertility (19, 20, 22, 23, 27-30). China Health and Nutrition Survey showed that MSG is responsible for development of obesity in human adults (31).

Negative influence of MSG on testes is documented by: decreased absolute and relative testes weights in treated animals (32-40), testicular atrophy and alterations of testis structure (38, 41-43), significant oligozoospermia and increased abnormal sperm morphology in adose-dependent fashion (44), and testicular hemorrhage, degene-ration and alteration of sperm cell population and morphology (42).

The way of MSG action is not completely explained yet. It is well known that MSG has high excitotoxic potential. We hypothesized that high concentration of MSG could alter permeability of neural membrane for calcium which could be involved in the mechanisms of MSG toxicity.

The objective of the present study was to examine whether the pretreatment with L-calcium channel blocker, diltiazem, may prevent toxic effect of MSG in Wistar rat testes.

\section{Materials and methods}

The study was carried out in 24 neonatal male Wistar rats. The pups were injected sub-cutaneously interscapulary on the $2^{\text {nd }}, 4^{\text {th }}, 6^{\text {th }}, 8^{\text {th }}$ and $10^{\text {th }}$ day of life with equal volume of: $0.9 \%$ of sodium chloride solution ( $C$ group), $4 \mathrm{mg} / \mathrm{g}$ BW of MSG (M group), $5 \mathrm{mg} / \mathrm{g}$ BW of diltiazem ( $D$ group) and $5 \mathrm{mg} / \mathrm{g} \mathrm{BW}$ of diltiazem and 60 minutes later with $4 \mathrm{mg} / \mathrm{g}$ BW of MSG (DM group). The animals were housed in standard cages under controlled laboratory conditions. The room temperature was 23 $\pm 2{ }^{\circ} \mathrm{C}$ and air humidity $50 \pm 5 \%$. The rhythm of light and darkness was established (light phase from 6.00 a.m. to 6.00 p.m.). The pups were weaned at age of 28 days and subsequently had free access to tap water and to standard laboratory chow pellets ("Veterinarski zavod" Zemun). The animals were sacrificed at the age of six months under pentobarbital sodium anesthesia (40 mg/kg BW intraperitoneally). Biometric parameters were measured: body weight, naso-anal length, tail length, absolute and relative testis weight and Lee index. The Lee index was used for assessment of obesity. It was calculated by the formula: cube root of body weight (g) $\times 10^{3} /$ naso-anal length $(\mathrm{mm})$ for each animal (4547).

The testes were carefully removed, cleaned of the surrounding tissue and weighed. The relative testis weight was then calculated as: absolute testis weight $(\mathrm{g}) /$ [body weight of rat $(\mathrm{g})$ ] $\times 100$ for each animal (48). The testis tissue was prepared according to appropriate procedures then stained routinely with periodic acid-Schiff (PAS) and with haematoxylin-eosin (H-E methods), later analyzed and described. Serial sections stained with haematoxylin and eosin were subject of histomorphological examinations. Histomorphometric analysis of the testes was performed on Leica microscope equipped with Leica DC 180 and DC 480 camera using Image J v1.39d. programme. The tubular diameter was measured on at least 30 randomly chosen tubular profiles of round or nearly round shape for each of 3 sections per animal. Area, perimeter and diameter were measured at $\times 20$ magnification. The height of the seminal epithelium was measured at $x 40$ magnification at randomly chosen tubular profiles of oval or round shape with at least 6 measurements per tubule, including the highest and the shortest part.

Results of statistical analysis are expressed as means \pm standard deviation (SD). Statistical significance was determined with analysis of variance (ANOVA) test. The differences were considered significant at $p<0.05$ or $p<0.001$ level. All statistical analyses were performed using the SPSS statistical software (Version 15). All procedures on animals followed Guideline for Work on Experimental Animals approved by the Ethic Committee of Faculty of Medicine, University of Niš.

\section{Results}

Statistically significant difference of mean values between analyzed groups was present in all analyzed biometric parameters except in body weight (Table 1). Parameters: naso-anal length, tail length, and Lee index in rats of $M$ group were significantly lower $(p<0.05)$ than in rats of the other groups ( $C, D$ and $D M)$. Absolute testis weight was significantly lower in rats of $M$ group than in rats of $C$ and D group. Relative testis weight was sig-nificantly lower in $M$ than in $D$ group of rats.

Histological examination revealed testicular atrophy in MSG treated rats. The most prominent histological changes in testes of MSG treated rats were: reduced diameters of the seminiferous tubules with decreased numbers of germ cells and decreased spermatogenesis, edematous interstitium and not prominent Leydig cells (Figure 1. M). Normal testicular histology was found in animals of control group, D and DM group (normal semini-ferous epithelium rich with developing germ cells through continuous spermatogenesis and the semi-niferous tubules containing spermatozoa) (Figure 1. C, D and DM).

Histomorphometric parameters: tubular area, tubular perimeter, Feret's diameter, tubular diameter and epithelial height were determined (Table 2). The lowest values of measured parameters were in group $M$ and they were significantly lower than in groups $D, D M$ and $C(p<0.001)$. The values of parameters in animals of group $C$ were significantly higher than in groups DM and $M$. The highest values of all measured parameters (tubular area, tubular perimeter, Feret's diameter, tubular diameter and epithelial height) were found in animals of group D. These parameters were significantly higher in group $D$ than in groups DM and $M$, but not significantly higher in group $D$ than in group $C$. All parameters in animals of group DM were significantly higher than in group $M$ and lower than in groups $D$ and $C$. 
Table 1. The mean values of biometric parameters in animals of $C, M, D$ and $D M$ group

\begin{tabular}{|c|c|c|c|c|}
\hline & \multicolumn{4}{|c|}{ Groups } \\
\hline & $\mathrm{C}$ & $\mathrm{M}$ & $\mathrm{D}$ & DM \\
\hline Body weight (g) & $531.67 \pm 27.69$ & $560.00 \pm 36.88$ & $528.33 \pm 33.71$ & $550.00 \pm 41.47$ \\
\hline Testis/AW (g) & $3.13 \pm 0.22$ & $2.60 \pm 0.31^{*,+}$ & $3.16 \pm 0.20$ & $3.20 \pm 0.27$ \\
\hline Testis/RW (g) & $0.59 \pm 0.05$ & $0.47 \pm 0.08^{\dagger}$ & $0.60 \pm 0.07$ & $0.59 \pm 0.09$ \\
\hline NA length $(\mathrm{cm})$ & $26.33 \pm 0.41$ & $23.58 \pm 0.92^{*,+, ~}$ & $26.00 \pm 0.63$ & $26.50 \pm 1.14$ \\
\hline Tail length $(\mathrm{cm})$ & $21.28 \pm 1.11$ & $19.58 \pm 0.80^{*,+, \neq}$ & $21.17 \pm 0.61$ & $22.25 \pm 0.42$ \\
\hline Lee index & $0.31 \pm 0.01$ & $0.34 \pm 0.02^{*,+, \neq}$ & $0.31 \pm 0.01$ & $0.31 \pm 0.01$ \\
\hline
\end{tabular}

C - control group treated with $0,9 \% \mathrm{NaCl}$;

$M$ - group treated with $4 \mathrm{mg} / \mathrm{g}$ of MSG;

$D$ - group treated with $5 \mathrm{mg} / \mathrm{g}$ of diltiazem;

DM - group treated with $5 \mathrm{mg} / \mathrm{g}$ of diltiazem and $4 \mathrm{mg} / \mathrm{g}$ of MSG;

AW - absolute weight; RW - relative weight; NA - naso-anal.

Results are expressed as means \pm standard deviation.

Statistically significant difference $(p<0.05)$ between: * $M$ and $C ;+M$ and $D ; \neq M$ and $D M$.

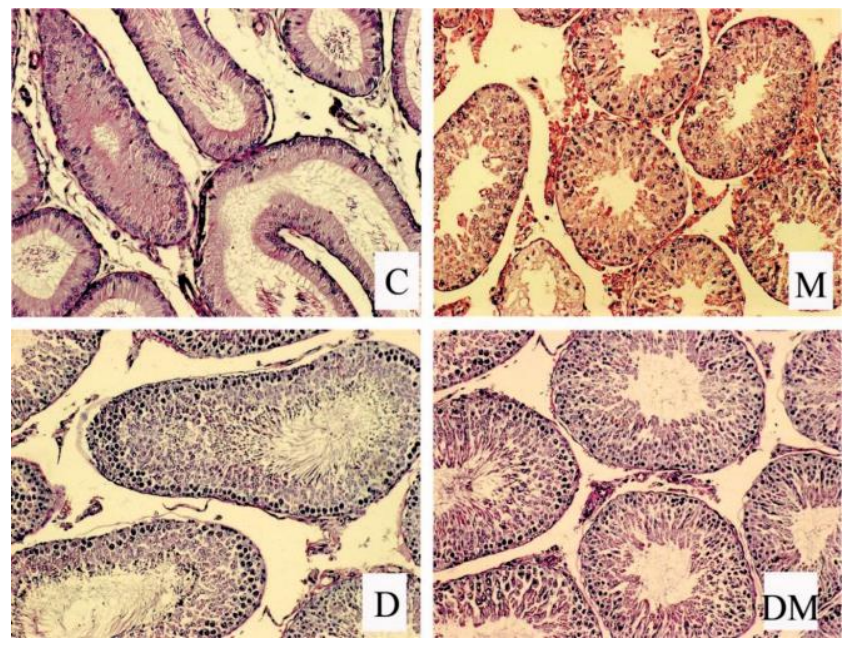

$\mathrm{C}$ - control group treated with $0.9 \% \mathrm{NaCl}$;

$\mathrm{M}$ - group treated with $4 \mathrm{mg} / \mathrm{g}$ of MSG;

D - group treated with $5 \mathrm{mg} / \mathrm{g}$ of diltiazem;

DM - group treated with $5 \mathrm{mg} / \mathrm{g}$ of diltiazem and $4 \mathrm{mg} / \mathrm{g}$ of MSG.

Figure 1. Section of testes of rats from $C, M, D$ and DM group; PAS stained; magnification $\times 40$.

Table 2. Mean values of testes morphometric parameters in animals of group $C, M, D$ and $D M$

\begin{tabular}{||l||c|c|c|c||}
\cline { 2 - 5 } \multicolumn{1}{c|}{} & \multicolumn{4}{c|}{ Groups } \\
\cline { 2 - 5 } \multicolumn{1}{c|}{} & C & M & D & DM \\
\hline \hline Tubular area & $77456.9 \pm 12231.4$ & $37818.0 \pm 9789.6$ & $82248.4 \pm 8137.8$ & $57028.0 \pm 11014.7$ \\
\hline Tubular perimeter & $1013.3 \pm 81.5$ & $712.2 \pm 88.4$ & $1037.9 \pm 55.8$ & $874.2 \pm 83.1$ \\
\hline Feret's diameter & $361.5 \pm 40.1$ & $258.7 \pm 33.5$ & $359.8 \pm 34.0$ & $313.7 \pm 36.5$ \\
\hline Tubule diameter & $289.4 \pm 25.1$ & $192.1 \pm 37.7$ & $291.5 \pm 25.9$ & $237.7 \pm 27.7$ \\
\hline Epithelial height & $48.6 \pm 9.6$ & $38.5 \pm 11.0$ & $48.0 \pm 11.3$ & $41.3 \pm 9.6$ \\
\hline
\end{tabular}

$\mathrm{C}$ - control group treated with $0.9 \% \mathrm{NaCl}$;

$\mathrm{M}$ - group treated with $4 \mathrm{mg} / \mathrm{g}$ of MSG;

$D$ - group treated with $5 \mathrm{mg} / \mathrm{g}$ of diltiazem;

DM - group treated with $5 \mathrm{mg} / \mathrm{g}$ of diltiazem and $4 \mathrm{mg} / \mathrm{g}$ of MSG.

Results are expressed as means \pm standard deviation. The values of measured parameters in group $M$ were significantly lower than in groups $D, D M$ and $C(p<0.001)$ 


\section{Discussion}

In recent years glutamate receptors has been given a very important role in pathogenesis of disorders induced by MSG. There are two basic types of glutamate receptors: ionotropic [N-methyl-D-aspartate (NMDA), a-amino-3-hydroxy-5-methyl-4-isoxazolepropionic acid (AMPA) and kainate] and metabotropic (mGluR) (31, 49-51). Glutamate receptors are present in different tissues: hypothalamus, heart, lungs, liver, kidneys, endocrine system, ovaries, uterus, testes, etc. (51-54).

It is referred that administration of high doses of MSG to adult Wistar rats, after two weeks, induced degenerative and atrophic changes in testes $(43,55)$. Also, increased apoptotic changes in the germinal epithelial cells and decreased germinal epithelial thickness were registered in adult Wistar rats treated with MSG ( $3 \mathrm{~g} / \mathrm{kg} / \mathrm{BW} /$ ) by gavage for 30 days (55).

These findings could be explained by effect of high concentration of MSG on glutamate receptors in peripheral tissues as testes. Activation of glutamate receptors by sustainable high concentration of MSG could alter ionic permeability of neural membrane and induce persistent depolarization $(26,56)$. Neural death can be induced by such excessive activation of glutamate receptors and overloading with intracellular calcium $(38,57)$.

The toxic effect of MSG on endocrine (male reproductive system) has been explained for years as the late consequence of hypothalamic nuclei impairment and persisting disturbances of the hypothalamic-pituitary-gonadal axis. Necrosis of hypothalamic structures is the most clearly demonstrated from three to five hours after application of MSG in neonatal animals. It is demonstrated that 24 hours after MSG application, necrotic cells are already phagocytized and signs of edema have disappeared (21, 27).

The presence of the central effect of MSG is well known, but its mechanism is not clear yet. In our experiment the effectiveness of the treatment with MSG is confirmed with the next findings: stunted growth (significantly shorter naso-anal and tail lengths) and obesity ( $p<0.05)$. Although the MSG treated rats were not significantly heavier than the controls, they were significantly more obese, what is confirmed with a significantly increased Lee index $(p<0.05)(45,58-62)$.

In MSG-treated rats, we registered a significant reduction in absolute weight of testes and gonadosomatic index (relative testis weight) compared with these parameters in rats of $C, D$ and $D M$ groups. Our results confirm findings of the studies which registered the decrease of gonadal weights in MSG treated animals (32-38, 40).

Decreased organ weight is a sign of toxic injury. In our study, marked testicular atrophy is shown by light microscopy in rats neonatally treated with MSG. We confirmed alterations in testes structure reported by other authors $(38,41-43,63,64)$.

Normal testicular histology was present in other groups of rats ( $C, D$ and $D M)$. These findings are strongly supported by the results of histomorphometric parameters analysis. We recorded highly significantly decreased values of histomorphometric parameters (tubular area, tubular perimeter, Feret's diameter, tubular diameter and epithelial height) $(p<0.001)$ in rats neonatally treated with MSG compared with parameters in rats of $C, D$ and DM group.

\section{Conclusion}

The results of our study show that the pretreatment with diltiazem is efficient in prevention of MSG toxicity on testes in Wistar rats. MSG harmful effects: stunted growth, decreased relative testis weight, increased adipose tissue mass, testicular atrophy and decreased histomorphometric parameters are prevented in rats pretreated with diltiazem. We consider that excessive activation of glutamate receptors and overloading with calcium could be responsible for neurotoxic potential of MSG. Subsequent studies should be done to elucidate if pretreatment with slow calcium channel-blocking agents could prevent toxic effect of MSG on testes in adult animals.

\section{Acknowledgment}

This research was supported by project 43012 of the Ministry of Science and Technological Development, Republic od Serbia. 


\section{References}

1. Takasaki Y. Protective effect of mono- and disaccharides on glutamate-induced brain damage in mice. Toxicol Lett 1979;4(3):205-10. [CrossRef]

2. Carlsen E, Giwercman A, Keiding N, Skakkebaek NE. Evidence for decreasing quality of semen during past 50 years. Br Med J 1992;305:609-13. [CrossRef] [PubMed]

3. Huang C, Li B, Xu K, Liu D, Hu J, Yang Y, et al. Decline in semen quality among 30,636 young Chinese men from 2001 to 2015. FertilSteril 2017;107(1):83-8. [CrossRef] [PubMed]

4. Sengupta P, Borges E Jr, Dutta S, Krajewska-Kulak E. Decline in sperm count in European men during the past 50 years. Hum Exp Toxicol 2018;37(3):247-55. [CrossRef] [PubMed]

5. Levine $H$, Jørgensen $N$, Martino-Andrade $A$, Mendiola J, Weksler-Derri D, Mindlis I, et al. Temporal trends in sperm count: a systematic review and meta-regression analysis. Hum Reprod Update 2017;23(6):64659. [CrossRef] [PubMed]

6. Mínguez-Alarcón L, Williams $P L$, Chiu $Y H$, Gaskins AJ, Nassan FL, Dadd R, et al. Earth Study Team. Secular trends in semen parameters among men attending a fertility center between 2000 and 2017: Identifying potential predictors. Environ Int 2018;121(Pt2):12971303. [CrossRef] [PubMed]

7. Homan GF, Davies M, Norman R. The impact of lifestyle factors on reproductive performance in the general population and those undergoing infertility treatment: a review. Hum Reprod Update 2007;13 (3): 209-23. [CrossRef] [PubMed]

8. Nordkap L, Joensen UN, Blomberg Jensen M, Jorgensen $\mathrm{N}$. Regional differences and temporal trends in male reproductive health disorders: semen quality may be a sensitive marker of environmental exposures. Mol Cell Endocrinol 2012;355(2):221-30.

[CrossRef] [PubMed]

9. Sengupta P. Environmental and occupational exposure of metals and their role in male reproductive functions. Drug Chem Toxicol 2013;36(3):353-68. [CrossRef] [PubMed]

10. Sengupta $P$, Banerjee R. Environmental toxins: alarming impacts of pesticides on male fertility. Hum Exp Toxicol 2014;33(10):1017-39. [CrossRef] [PubMed]

11. Nnadozie JO, Chijioke UO, Okafor OC, Olusina DB, Oli AN, Nwonu PC, et al. Chronic toxicity of low dose monosodium glutamate in albino Wistar rats. BMC Res Notes 2020;13(1):21. [CrossRef] [PubMed]

12. Kurihara K. Umami the fifth basic taste: history of studies on receptor mechanisms and role as a food flavor. BioMed Res Int 2015;2015:189402. [CrossRef] [PubMed]

13. Zanfirescu A, Ungurianu A, Tsatsakis AM, Nițulescu GM, Kouretas D, Veskoukis A, et al. A review of the alleged health hazards of monosodium glutamate. Comprehensive reviews in food science and food safety. 2019;18(4):1111-34. [CrossRef] [PubMed]

14. Airaodion AI, Ogbuagu EO, Osemwowa EU, Ogbuagu $U$, Esonu CE, Agunbiade AP, et al. Toxicological effect of monosodium glutamate in seasonings on human health. Glob J Nutri Food Sci 2019;1(5):1-9. [CrossRef]

15. Lucas DR, Newhouse JP. The toxic effect of sodium Lglutamate on the inner layers of the retina. AMA Arch Opthalmol 1957;58(2):193-201. [CrossRef] [PubMed]

16. Potts AM, Modrell KW, Kingsbury C. Permanent fractionation of the electroretinogram by the sodium glutamate. Am J Ophtalmol 1960;59:900-7. [CrossRef] [PubMed]
17. Cohen AI. An electron microscopic study of the modification by monosodium glutamate of the retinas of normal and rod-less mice. Am J Anat 1967;120(2): 319-56. [CrossRef]

18. Olney JW. Brain lesions, obesity, and other disturbances in mice treated with monosodium glutamate. Science 1969;164:719-21. [CrossRef] [PubMed]

19. Olney JW, Ho OL. Brain damage in infant mice following oral intake of glutamate, aspartate or cysteine. Nature 1970;227:609-11. [CrossRef] [PubMed]

20. Olney JW, Ho OL, Rhee V. Cytotoxic effects of acidic and sulphur containing amino acids on the infant mouse central nervous system. Exp Brain Res 1971; 14(1):61-76. [CrossRef] [PubMed]

21. Olney JW. Glutamate-induced neuronal necrosis in the infant mouse hypothalamus. An electron microscopic study. J Neuropathol Exp Neurol 1971;30(1):75-90. [CrossRef] [PubMed]

22. Olney JW, Sharpe LG, Feigin RD. Glutamate-induced brain damage in infant primates. J Neuropathol Exp Neurol 1972;31(3):464-88. [CrossRef] [PubMed]

23. Lemkey-Johnston $N$, Reynolds WA. Incidence and extent of brain lesions in mice following ingestion of monosodium glutamate (MSG). Anat Rec 1972;172: 354.

24. Lemkey-Johnston N, Reynolds WA. Nature and extent of brain lesions in mice related to ingestion of monosodium glutamate. A light and electron microscope study. J Neuropathol Exp Neurol 1974;33(1):74-97. [CrossRef] [PubMed]

25. Sasaki $F$, Sano M. Roles of the arcuate nucleus and ovary in the maturation of growth hormone, prolactin, and nongranulated cells in the mouse adenohypophysis during postnatal development: a stereological morphometric study by electron microscopy. Endocrinology 1986;119(4):1682-9. [CrossRef] [PubMed]

26. Gao J, Wu J, Zhao XN, Zhang WN, Zhang YY, Zhang $Z X$. Transplacental neurotoxic effects of monosodium glutamate on structures and functions of specific brain areas of filial mice. Sheng Li Xue Bao 1994;46(1):4451. [PubMed]

27. Burde RM, Schainker B, Kayes J. Acute effect of oral and subcutaneous administration of monosodium glutamate on the arcuate nucleus of the hypothalamus in mice and rats. Nature 1971;233:58-60. [CrossRef] [PubMed]

28. Burde RM, Schainker B, Kayes J. Monosodium glutamate: necrosis of hypothalamic neurons in infant rats and mice following either oral or subcutaneous administration. J Neuropathol Exp Neurol 1972;31(1):181.

29. Takasaki Y, Yugari Y. Protective effect of arginine, leucine, and preinjection of insulin on glutamate neurotoxicity in mice. Toxicol Lett 1980;5(1):39-44. [CrossRef] [PubMed]

30. Terry LC, Epelbaum J, Martin JB. Monosodium glutamate: acute and chronic effects on rhythmic growth hormone and prolactin secretion and somatostatin in the undisturbed male rat. Brain Res 1981;217(1): 129-42. [CrossRef] [PubMed]

31. He K, Du S, Xun P, Sharma S, Wang H, Zhai F, et al. Consumption of monosodium glutamate in relation to incidence of overweight in Chinese adults: China Health and Nutrition Survey (CHNS). Am J Clin Nutr 2011;93(6):1328-36. [CrossRef] [PubMed]

32. Redding TW, Schally AV, Arimura A, Wakabayashi I. Effect of monosodium glutamate on some endocrine functions. Neuroendocrinology 1971;8(3-4):245-55. [CrossRef] [PubMed] 
33. Pizzi WJ, Barnhart JE, Fanslow DJ. Monosodium glutamate administration to the newborn reduces reproductive ability in female and male mice. Science 1977; 196:452-4. [CrossRef] [PubMed]

34. Clemens JA, Roush ME, Fuller RW, Shaar CJ. Changes in luteinizing hormone and prolactin control mechanisms produced by glutamate lesions of the arcuate nucleus. Endocrinology 1978;103(4):1304-12. [CrossRef] [PubMed]

35. Bakke JL, Lawrence N, Bennett J, Robinson S, Bowers CY. Late endocrine effects of administering monosodium glutamate to neonatal rats. Neuroendocrinology 1978;26(4):220-8. [CrossRef] [PubMed]

36. Waxman DJ, Morrisey JJ, MacLeod JN, Shapiro HK. Depletion of serum growth hormone in adult female rats by neonatal monosodium glutamate treatment without loss of female-specific hepatic enzymes P-450 2d (IIC12) and steroid 5a-reductase. Endocrinology 1990;126(2):712-20. [CrossRef] [PubMed]

37. Miskowiak B, Limanowski A, Partyka M. Effect of perinatal administration of monosodium glutamate (MSG) on the reproductive system of the male rat. Endokrynol Pol 1993;44(4):499-505. [PubMed]

38. Bojanic V. Experimental study of pathogenesis of monosodium glutamate induced obesity [dissertation]. Nis: Nis Univ.;1998. (in Serbian)

39. Katić K, Najman S, Cekić S, Bojanić V, Katić V. Hypothalamic lesions in mice treated with monosodium glutamate. Arch Oncol 2001;9:159-60.

40. Nayanatara AK, Vinodini NA, Damodar G, Ahemed B, Ramaswamy $C R$, Shabarianth $M$, et al. Role of ascorbic acid in monosodium glutamate mediated effect on testicular weight, sperm morphology and sperm count in rat testis. J Chin Clin Med 2008;3:1-5.

41. Katić V, Najman S, Stanković T, Matijaš M, Katić K. Testicular function and morphology in mice treated with MSG (monosodium glutamate). Pathol Res Pract 1997; 193(5-6):385.

42. Oforofuo IAO, Onakewhor JUE, Idaewor PE. The effect of chronic administration of MSG on the histology of the adult Wistar rat testes. Bio Res Comm 1997;9(2): 30-56.

43. Eweka AO, Om'Iniabohs FAE. Histological studies of the effects of monosodium glutamate on the testis of adult Wistar rats. The Internet Journal of Urology 2008;5(1).

44. Onakewhor JUE, Oforofuo IAO, Singh SP. Chronic administration of monosodium glutamate induces oligozoospermia and glycogen accumulation in Wistar rat testes. Afr J Reprod Health 1998;2(2):190-7.

45. Bernardis LL, Patterson BD. Correlation between 'Lee index' and carcass fat content in weanling and adult female rats with hypothalamic lesions. J Endocrinol 1968;40(4):527-8. [CrossRef] [PubMed]

46. Poon TK, Cameron DP. Measurement of oxygen consumption and locomotor activity in monosodium glutamate-induced obesity. Am J Physiol 1978;234(5): E532-4. [CrossRef] [PubMed]

47. Bernardis LL, Luboshitsky R, Bellinger LL, McEwen G. Nutritional studies in the weanling rat with normophagic hypothalamic obesity. J Nutr 1982;112(7): 1441-55. [CrossRef] [PubMed]

48. Shapiro BH, MacLeod JN, Pampori NA, Morrissey JJ, Lapenson DP, Waxman DJ. Signaling elements in the ultradian rhythm of circulating growth hormone regulating expression of sex-dependent forms of hepatic cytochrome P450. Endocrinology 1989;125(6):293544. [CrossRef] [PubMed]

49. Caruso C, Bottino MC, Pampillo M, Pisera D, Jaita G, Duvilanski $B$, et al. Glutamate induces apoptosis in anterior pituitary cells through group II metabotropic glutamate receptor activation. Endocrinology 2004; 145(10):1677-84. [CrossRef] [PubMed]

50. Gerber U, Gee CE, Benquet P. Metabotropic glutamate receptors: intracellular signaling pathways. Curr Opin Pharmacol 2007;7(1):56-61. [CrossRef] [PubMed]

51. Husarova V, Ostatnikova D. Monosodium glutamate toxic effects and their implications for human intake: a review. JMED Research 2013;2013:1-12. [CrossRef]

52. Gill S, Pulido O. Glutamate receptors in peripheral tissues. Distribution, and implications for toxicology. In: Gill S, Pulido O, editors. Glutamate receptors in peripheral tissue: excitatory transmission outside the CNS. New York: Kluwer Academic/Plenum Publishers; 2005. p. 3-26. [CrossRef]

53. Gill S, Barker M, Pulido O. Neuroexcitatory targets in the female reproductive system of the nonhuman primate (Macacafascicularis). ToxicolPathol 2008;36 (3): 478-84. [CrossRef] [PubMed]

54. Bolton C, Paul C. Glutamate receptors in neuroinflammatory demyelinating disease. Mediators Inflamm 2006;2006(2):93684. [CrossRef] [PubMed]

55. Rahimi Anbarkeh F, Baradaran R, Ghandy N, Jalali M, Nikravesh MR, Soukhtanloo M. Effects of monosodium glutamate on apoptosis of germ cells in testicular tissue of adult rat: An experimental study. Int J Reprod BioMed 2019;17(4):261-70.

[CrossRef] [PubMed]

56. Beas-Zárate C, Rivera-Huizar SV, Martinez-Contreras A, Feria-Velasco A, Armendariz-Borunda J. Changes in NMDA-receptor gene expression are associated with neurotoxicity induced neonatally by glutamate in the rat brain. Neurochem Int 2001;39(1):1-10. [CrossRef] [PubMed]

57. Gil-Loyzaga P, Hernandez-Ortiz MJ, Rodriguez-Benito $T$, Lasso de la Vega ML. Diltiazem protects against neurotoxicity induced by excitotoxic amino acids on cochlear afferent fibers. ORL J Otorhinolaryngol Relat Spec 1993;55(4):211-5 [CrossRef] [PubMed]

58. Nakai T, Tamai T, Takai H, Hayashi S, Fujiwara $R$, Miyabo S. Decreased ketonaemia in the monosodium glutamate-induced obese rats. Life Sci 1986;38(22): 2009-13. [CrossRef] [PubMed]

59. Smith $Y$, Charara $A$, Paquet $M$, Kieval JZ, Paré JF, Hanson JE, et al. Ionotropic and metabotropic GABA and glutamate receptors in primate basal ganglia. J Chem Neuroanat 2001;22(1-2):13-42.

[CrossRef] [PubMed]

60. Weston MC, Gertler C, Mayer ML, Rosenmund C. Interdomain interactions in AMPA and kainate receptors regulate affinity for glutamate. J Neurosci 2006; 26(29):7650-8. [CrossRef] [PubMed]

61. Vinodini NA, Nayanatara AK, Damodara Gowda KM, Ahamed B, Ramaswamy CR, Shabarianth $M$, et al. Effect of monosodium glutamate-induced oxidative damage on rat testis. J Chin Clin Med 2008;3:370-3.

62. Campos KE, Volpato GT, Calderon IMP, Rudge MVC, Damasceno DC. Effect of obesity on rat reproduction and on the development of their adult offspring. Braz J Med Biol Res 2008;41(2):122-5.

[CrossRef] [PubMed]

63. Jubaidi FF, Mathialagan RD, Noor MM, Taib IS, Budin SB. Monosodium glutamate daily oral supplementation: study of its effects on male reproductive system on rat model. Syst Biol Reprod Med 2019;65(3):194204. [CrossRef] [PubMed]

64. Hamza RZ, Diab AEA. Testicular protective and antioxidant effects of selenium nanoparticles on Monosodium glutamate-induced testicular structure alterations in male mice. Toxicol Rep 2020;7: 254-60. [CrossRef] [PubMed] 
Revijalni rad

UDC: 615.22:[636.087.7:547.466.64

doi: $10.5633 / \mathrm{amm} .2020 .0303$

\title{
DILTIAZEM SPREČAVA TOKSIČNI UTICAJ MONONATRIJUM GLUTAMATA NA TESTISE PACOVA
}

\author{
Vladmila Bojanić ${ }^{1}$, Stevo Najman ${ }^{2}$, Aleksandra Veličkov ${ }^{3}$, Novica Bojanić $^{4}$, Jelena Milenković ${ }^{1}$
}

${ }^{1}$ Univerzitet u Nišu, Medicinski fakultet, Katedra za patološku fiziologiju, Niš, Srbija

¿Univerzitet u Nišu, Medicinski fakultet, Institut za biologiju sa humanom genetikom, Niš, Srbija

${ }^{3}$ Univerzitet u Nišu, Medicinski fakultet, Katedra za histologiju i embriologiju, Niš, Srbija

${ }^{4}$ Univerzitet u Nišu, Medicinski fakultet, Naučnoistraživački centar za biomedicinu, Niš, Srbija

Kontakt: Vladmila Bojanić

Pariske komune 11/37, 18000 Niš, Srbija

E-mail: vladmilab@gmail.com

Povećana izloženost aditivima hrani može uticati štetno na muški reproduktivni sistem. Neonatalna aplikacija velikih doza mononatrijum glutamata (MNG), popularnog poboljšivača ukusa, u neonatalnom periodu kod raznih životinjskih vrsta izaziva lezije u jedrima hipotalamusa i mrežnjači. Kasnije, u odraslom periodu, životinje pokazuju niz neuroendokrinih poremećaja: zastoj u rastu, gojaznost i smanjen fertilitet. Mehanizam delovanja MNG-a još nije u potpunosti objašnjen. Pretpostavili smo da velika koncentracija MNG-a može izmeniti propusnost membrane neurona za kalcijum. Cilj naše studije je proučavanje mogućnosti sprečavanja štetnih efekata MNG-a na testise pacova pretretmanom diltiazemom. Mužjaci pacova tretirani su: 0,9\% natrijum hloridom (C grupa), 4 mg/g TM MNG-a (M grupa), $5 \mathrm{~m} / \mathrm{g}$ TM diltiazemom (D grupa) i $5 \mathrm{~m} / \mathrm{g}$ TM diltiazemom sa MNG-om (DM grupa) drugog, četvrtog, šestog, osmog i desetog postnatalnog dana. Životinje su žrtvovane posle šest meseci. Kod pacova tretiranih MNG-om registrovani su: zastoj u rastu (smanjena nazo-analna dužina i dužina repa; $p<0,05)$, smanjene relativne mase testisa $(p<0,05)$ i povećanje količine masnog tkiva (povećan Lee indeks; $p<0,05$ ), atrofija testisa i smanjenje histomorfometrijskih parametara testisa: tubularne aree, tubularnog perimetra, Feret dijametra, tubularnog dijametra i visine epitela $(p<0,001)$. Pacovi C, D i DM grupa imali su normalnu histologiju i morfometrijske parametre. Prethodno tretiranje diltiazemom sprečilo je preopterećenje ćelija kalcijumom i razvoj morfoloških poremećaja testisa. Naši rezultati sugerišu to da preopterećenje ćelija kalcijumom spada u mehanizme toksičnog delovanju MNG-a na testise.

Acta Medica Medianae 2020;59(3):20-26. toksičnost

Ključne reči: mononatrijum glutamat, diltiazem, morfometrijski parametri, testisi, 